\title{
Âlemin Aslî Maddesi Bağlamında Ortaya Çıkan Farklı Görüşlerin İtikat Açısından Sonuçları
}

\section{The Results of Different Opinions About the Basic Material of the Universe in Terms of Faith}

\author{
Hasan GÜMÜŞOĞLU \\ Doç. Dr., Yalova Üniversitesi, İslami Ilimler Fakültesi, İslam Mezhepleri Tarihi Anabilim Dalı \\ Associate Professor, Yalova University, Faculty of Islamic Sciences, Department of History of Islamic Sects \\ Yalova, Turkey \\ hasgumus@hotmail.com \\ orcid.org/0000-0002-0836-4031
}

\author{
Makale Bilgisi / Article Information \\ Makale Türü / Article Types : : Araştırma Makalesi / Research Article \\ Geliş Tarihi / Received : :5 Mart / March 2019 \\ Kabul Tarihi / Accepted $\quad$ : 11 Mayıs / May 2019 \\ Yayın Tarihi / Published $\quad$ : 15 Haziran / June 2019 \\ Yayın Sezonu / Pub Date Season : Haziran / June \\ Cilt / Volume: 6 - Sayı / Issue: 1 - Sayfa / Pages: 49-70
}

Atıf / Cite as

Gümüşoğlu, Hasan. "Âlemin Aslî Maddesi Bağlamında Ortaya Çıkan Farklı Görüşlerin İtikat Açısından Sonuçları". Bülent Ecevit Üniversitesi Ilahiyat Fakültesi Dergisi, 6/1 (2019): 49-70.

Doi: 10.33460/beuifd.535851

Intihal / Plagiarism

Bu makale, en az iki hakem tarafından incelendi ve intihal içermediği teyit edildi.

This article has been reviewed by at least two referees and scanned via a plagiarism software.

Yayın Hakkı / Copyright ${ }^{\circ}$

Zonguldak Bülent Ecevit Üniversitesi, İlahiyat Fakültesi tarafından yayınlanmıștır. Tüm hakları saklıdır.

Published by Zonguldak Bulent Ecevit University, Faculty of Theology, Zonguldak, Turkey. All rights reserved.

Öz: Düşünce tarihi boyunca âlemin aslî bir maddesi olup olmadığı hep merak edilmiş ve bu konuda filozoflar, kelamcılar ve mutasavviflar farklı görüşler ortaya koymuşlardır. Geçtiğimiz asırda fizik ilminde meydan gelen büyük ilerlemeler neticesinde atomun bir enerji deposu olduğunun anlaşılması, insanların dikkatini tekrar bu konuya çekmiştir.

Âlemin aslî maddesi konusu ìslâm itikadının aslî bir meselesi olmamakla birlikte, konu ortaya konulurken heyûlâ, adem, vücûd, atom (cüz-i lâ yetecezzâ, cevher-i ferd) gibi kavramlara yüklenen bazı manalar, İslâm itikadının konusuna giren esaslarla ilişkili olduğundan bu konu itikadî bir boyut kazanmıştır. Bu makalede, söz konusu kavramlara yüklenen manaları itikad açısından sonuçlarını incelenmeye çalışılmıştır.

Fârâbî ve íbn Sînâ, ilk varlıktan (Allah'tan) diğer varlıkların sudûrunu açıklarken âlemin meydana gelmesinde Allah'ın tesirini kabul etmeyen Aristo'dan ayrılmışlar. Bazı filozof ve mutasavvıfların varlık konusundaki görüşlerini tenkit eden İmâm-ı Rabbânî ise, heyûlânın varlığını veya yokluğunu kabul etmekten ziyade ona atfedilen mananın önemli 
olduğuna işaret ederek, âlemin Allah'ın iradesiyle ve kudretiyle sonradan yaratılmış olduğunu açık bir şekilde belirtmiştir.

Anahtar Kelimeler: Kelam, Itikat, Varlık, Atom, Adem, Heyulâ, Cevher

Abstract: It has always been a wonder along the history of thought whether a basic material for the universe existed; and philosophers, theologians, and sufis have put forward different opinions in this matter. As a result of the great progress in the science of physics in the past century, the fact that it was understood that the atom was an energy depot attracted the attention of people.

Although the views that have emerged around the basic material of the universe constitute an essential matter of the Islamic faith, the issue has gained a dogmatic dimension because some of the meanings imposed on concepts such as hayula, adam, wujud, atom (juz-i lâ yetecezzâ, jawhar-i ferd) are related to the principles of Islamic faith. In this article, the results of the meanings attributed to these concepts are examined in terms of the faith.

Farabi and Ibn Ibn Sînâ, differed from Aristotle who did not accept the influence of Allah in the existence of the universe. Imam-ı Rabbâni, criticizing the views of some philosophers and Sufis on the matter of existence, clearly stated, by implying that the meaning attributed to hayula was important rather than accepting its existence or absence, that universe was created by Allah's will.

Key Words: Theology, Faith, Existence, Atom, Heyula, Non-being, Jawhar.

\section{GíRiş}

İnsanlık tarihi boyunca varlık meselesi etrafında pek çok şey yazılmış olmakla birlikte, çalışmamız esnasında atıfta bulunduğumuz kaynaklardan da anlaşılacağı üzere özellikle filozoflar, mutasavvıflar ve kelamcılar, konuyla daha yakından ilgilenmişlerdir. Günümüzde de konuyla alakalı olarak, bazıları yüksek lisans ve doktora tezi olmak üzere pek çok çalışma yapılmakla birlikte söz konusu çalışmalar genellikle ya şahıs bazında veya sadece bir belirli bir bilim dalı ekseninde olmuştur. Biz konuya makale bazında farklı bir açıdan bakarak felsefe, kelam ve tasavvuf ehli tarafından varlık meselesinde ifade edilen görüşlerin kısa bir mukayesesini yapıp, farklı görüşlerin itikadî açıdan sonuçlarını ortaya koymaya çalışacağız. Bunun için de öncelikle varlık meselesi incelenirken kullanılan temel kavramlar hakkındaki görüşlere yer vereceğiz.

\section{VARLIK MESELESINDE TEMEL KAVRAMLAR}

Düşünce tarihinde "varlık" meselesi ekseninde âlemin aslının ne olduğu ve Allah'ın âlem ile olan münasebeti konusu, ilim adamlarını sürekli meşgul etmiştir. Özellikle Eflatun'un (M.Ö. 427-347) ilk varlıktan (madde) söz ederken onun, aklî idelerden veya maddi olmayan suretlerden ibaret olduğunu söylemesi ve 
Aristo'nun (M.Ö. 384-322) heyûlânın tek başına varlığının imkansız olduğunu belirtip, onun ezelî olduğunu ifade etmesi, vücûd, adem, atom ve heyulâ gibi kavramların ön plana çıkmasında etkili olmuştur. Bu itibarla biz, makalemize öncelikler bu kavramlara kısa bir atf-ı nazar ederek başlayacağız.

\subsection{Vücûd}

Antikçağ Yunan felsefesinde yer alan varlık-yokluk tartışmasında, filozoflar yokluktan bir şeyin meydana gelmeyeceğini söyleyerek, maddenin (heyûlâ) ezelî ve ebedî olduğunu ileri sürmüşlerdir. Onlara göre madde, kendi kendine var olmuştur, başlangıcı ve sonu yoktur, hiçbir şey yoktan var olmaz ve hiç bir şey de yok olmaz. ${ }^{1}$ Aristo'ya göre varlık ve yokluk iki zıt ilke olup bunların gerçeklik kazanabilmesi için bir dayanağa ihtiyaç vardır. Madde sırf kuvvet olduğundan suret ile birleşmeksizin fiilen gerçekleşemez. Ayrıca varlık kendini maddede ortaya koyduğundan, yokluk gerçeklik kazanamamıştır. ${ }^{2}$

İslâm âlimleri genel manada âlemin yoktan var edildiğini kabul etmekle birlikte vücûd (varlık) veya ma'dum'un mahiyeti konusunda farklı açıklamalarda bulunmuşlardır. Bu çerçevede varlığın, ilk müşahede edilen ve tasavvuru apaçık olan şey olması itibariyle tarife ihtiyacının bulunmadığı, hatta vücûd'dan daha iyi bilinen bir şeyin olmadığı ifade edilmiştir. ${ }^{3}$ Vücûd, "sabit olan, gözle görülen, kendisinden haber verilen şey", fâil veya mef'ul, yahut hâdis veya kadîm" şeklinde tarif edilmeye çalışılsa da Sa'düddîn Teftazânî (ö.793/1390), bunları yeterli görmemiş ve vücûdun aklen bu izahlardan daha açık olduğuna dikkat çekmiştir. ${ }^{4}$

Kâdı Ebû Bekir el-Bâkillânî (ö.403/1013), mevcudâtı, kadîm ve muhdes olmak üzere ikiye ayırır ve muhdesin yokluktan (adem) var olduğunu belirterek onu cisim, cevher ve araz olarak üçe taksim edip âlemin, Allah tarafından yaratıldığını ispat etmeye çalışır. İbn Fûrek (ö.406/1015), Ebu'l-Hasen el-Eş'arî'den (ö. 324/941) naklen menfi (olumsuzluk) ile ma'dûm, müsbet ile mevcûd arasında ilişki kurarak, "şey" demenin ispat manasına geldiğini şey olmayanın (lâ şey') ise nefyetmek manasına geldiğini söyleyerek ma'dûmun şey diye isimlendirilmesinin tenakuz olduğunu belirtmiştir. $\mathrm{O}$, ayrıca ma'dûmun isimlendirilmesinin veya cevher

1 Aristoteles, Metafizik, trc. Ahmet Aslan, (İstanbul: Sosyal Yayınları, 1985), 90-5, 308; Orhan Hançerlioğlu, Felsefe Ansiklopedisi (Kavramlar ve Akımlar) (İstanbul: Remzi Kitabevi, 1978), 5: 53; Yaşar Aydınlı, Fârâbî, (İstanbul: TDV Yayınları, 2017), 80.

2 Aristoteles, Metafizik, 312, 363; Ebû Nasr Muhammed el-Fârâbî, Ârâu ehli'l-medineti'l-fâzılâ (Kâhire: Matbaatü'sSaâde, 1906), 27-8; Osman Karadeniz, "Heyûlâ", Türkiye Diyanet Vakfı İlâm Ansiklopedisi (İstanbul: TDV Yayınları, 1998), 17: 294.

3 Hüseyin b. Abdullah b. Sînâ, el-ļsârât ve't-tenbihât, nşr. Süleyman Dünyâ (Kâhire: Dâru'l-Maârif, 1985), 3: 299; Abdülkerîm,Şehristânî, Nihâyetü'l-ikdâm, nşr. Alfred Guilaume (Kâhire: Mektebetü's-Sekâfeti'd-Dîniyye, 2009), 146, İbrahim Kalın, Varlık ve İdrak Molla Sadrấnın Bilgi Tasavvuru, trc. Nurullah Koltaş, (İstanbul: Klasik 2017), 89.

4 Sa'deddîn Teftazânî, Şerhu'I-Makâsıd, nşr. Abdurrahman U'meyrâ (Beyrut: Âlemü'l-Kütüb, 1989), 1: 295.

5 Kâdı Ebû Bekir el-Bâkıllânî, Kitâbü't-Temhîd, nşr. Imâdüddîn Ahmed Haydâr (Beyrut: Müessetü'l-Kütübi'sSekâfiyye, 1987), 37-43. 
ve araz gibi cismin vasıflarıyla tavsif edilmesinin sahih olmadığını ifade edip, ma'dûmun işitilmesinin ve görülmesinin sahih olmadığını söylemiştir. ${ }^{6}$

Ebü'I-Yüsr Pezdevî (ö.493/1100), Ehl-i sünnet ve cemaat'in “ma'dûm; şey, araz, cevher ve cisim değildir"dediğini belirtir. Ehl-i sünnet'in"Daha önce hiçbir şey değil iken biz onu (insanı) yarattık" (Meryem, 19/67) âyetini buna delil olarak getirdiğini söyleyen Pezdevî, bu nassa göre vücûd bulmayana şey denilemeyeceğini ifade eder.7 Ebu'l-Muîn en-Nesefî (ö.508/1115) ise, kadimi "ademliği (yokluğu) muhal olan" diye açıklar ve kadîmin vacibü'l-vücûd (varlığı zorunlu) olduğunu belirterek, vücûdu mümkün (câizü'l-vücûd) olanın, yokluğunun da mümkün (câizü'ladem) olduğunu söyler. $\mathrm{O}$, mümkün olmakta varlık ve yokluğun aynı derecede olmasından dolayı ikisinin de bir muhassısın tahsısına ihtiyacının bulunduğunu bunun ise muhdesin özelliği olduğuna dikkat çeker ve sadece kadîm olan vâcibü'l-vücûdun (Allah) buna ihtiyacının olmadığını söyler. ${ }^{8}$

İbn Fûrek, "mevcûd olmadığını bildim” demenin doğru olduğu gibi “ilmü'lma'dûm" ifadesini kullanmanın mümkün olduğunu belirterek ileride olacağına binaen ma'duma şey isminin kullanılmasının sahih olduğunu ifade eder. Bu konuda "Kıyamet sarsıntısı çok büyük bir şeydir" (Hac, 22/1) ve "Biz bir şeyin olmasını istediğimiz zaman sözümüz sadece ona "ol" dememizdir. O da hemen olur" (en-Nahl, 16/40) âyetlerini delil getiren İbn Fûrek, Hz. Yusuf'un (a.s.) hapishanedeki arkadaşının sözünü anlatan âyette "Ben rüyamda şarap sıktığımı gördüm" dediğini hatırlatır. Hâlbuki burada sıkılanın şarap olmayıp, üzümdür ve ileride şarap olacağı için mecazen üzüm için şarap lafzı kullanılmıştır. ${ }^{9}$

Âlemin aslî maddesi ekseninde önemli bir tartışma konusu olan "ma'dumun şeyliği" konusu, gerek Mu'tezile gerekse Ehl-i sünnet kelamcılar tarafından daha çok m'adumun Allah'ın ilim ve kudretiyle ilişkisi bağlamında ele alınmıştır. ${ }^{10}$ Âlemin yoktan var edildiğini söyleyen Ehl-i sünnet ulemâsı, yokluğu bir varlık olarak kabul etmeyip ona "şey" denilmesini doğru bulmazken" Mu'tezile, meseleye Allah Teâlâ'nın ilmi açısından yaklaşmıştır.

Kâdı Abdulcebbâr, malûmun mevcûd ve ma'dûm olmaktan, mevcûdun ise kadîm ve hadis olmaktan hali olmayacağını söyleyerek, Allah’ın zâtıyla âlim olduğunu belirtir ve Allah'ın ilminde bir değişiklik olmayacağına dikkat çekerek ${ }^{12}$ ma'dûmun Allah'ın ilminde bulunmasından hareketle ona şey denilebileceğine

6 Ebû Bekr Muhammed b. el-Hasen İbn Fûrek, Mücerredü Makâlâtu'ş- Şeyh Ebî'l-Hasen el-Eşa'rî, nşr. Ahmed Abdurrahîm es-Sâyah (Kâhire: Mektebetü's-Sekâfeti'd-Dîniyye, 2005), 262-4.

7 Ebü'l-Yüsr Muhammed Pezdevî, Usûlü'd-dîn, nşr. H.P. Lins (Kâhire: Dâru İhyâi'l-Kütübi'l-Arabiyye, 1963), 214.

8 Ebü'I-Muîn en-Nesefi, Tebsıratu'l-edille fi usûli'd-dîn, nşr. Claude Salâme (Dımaşk: y.y. 1993), 1:61-2.

9 İbn Fûrek, Makâlâtu'ş-Şeyh Ebî'l-Hasen, 262.

10 M. Cüneyt Kaya, Varlık ve Imkân Aristoteles'ten Ibn Sînâ'ya Imkânın Tarihi, (İstanbul: Klasik, 2011), 148.

11 Sa'deddîn Teftazânî, Şerhu'l-Akâid (İstanbul: Şerket-i Sahâfî-i Osmâniyye Matbaası, 1326), 192; Aliyyü'l-kârî, Dav'ü'l-meâlîfî şerhi Bed'i'l-Emâlî (istanbul: y.y. ts,), 35.

12 Kâdı Abdulcebbâr, Şerhu'I-Usûli'I-hamse, nşr. Ahmed b. el-Hüseyn b. Ebî Hâşim (Beyrut: Dâru İhyâi't-Türâsi'lArabî, 2001), 120. 
ifade eder. Mu'tezile, ma'dûmun zikredilmesini, bilinmesini, vasıflanmasını ve isimlenmesini dikkate alarak ona şey denilebileceğini, Allah Teâlâ'nın ma'dûmları bildiğini, şey olmayana ise ilmin taalluk etmeyeceğini söyler. ${ }^{13}$

\subsection{Adem}

Eflatun, yokluğu, İde'nin âlemi var etmek için kullandığı ilk madde olarak kabul edip, onun gerçek bir varlığının bulunduğunu söylemiştir. Eflatun, âlemin sonradan yaratılmış olduğu fikrine sahip olmakla birlikte sonradan gelen bazı filozoflar, onun bu görüşünü tevil ederek âlemin sonradan yaratıldığı görüşünü inkâr etmişlerdir. ${ }^{14}$

Aristo, ademi (yokluğu), "varlığın yokluğu" manasında kullandığından onu, gerçek bir varlık gibi görmemiştir. Ona göre varlık, var olan bir olgu sayesinde meydana gelir ve her bakımdan yok olan bir şeyden bir varlığın meydan gelmesi düşünülemez. ${ }^{15}$ Aristo, âlemin yoktan var edildiğini kabul etmemekle, Allah'ın iradesinin âlemin yaratılmasına taallukunu da inkâr etmiş̧tir.

İlme konu olan hususları (ma'lumât) ma'dûm ve mevcûd olmak üzere ikiye ayıran Bâkillânî, mevcûdun sabit olan şey manasına, ma'dûmun ise müntefi (olumsuzluk) yani şey olmayan (lâ şey) manasına geldiğini belirtir. Ma'dûmu çeşitli kısımlara ayıran Bâkillânî, ma'dûm ma'lum olarak isimlendirdiği kısmı; muhal ve mümteni olarak vasıflayıp, bunun henüz var olmadığı gibi ebediyen de vücut bulmasının mümkün olmadığını söyler ve iki zıddı cem etmeyi buna misal olarak verir. O, ikinci kısımda; ma'dûmun var olması mümkün olmakla birlikte var olmadığını ileride de ebediyen var olmayacağını Allah'ın bildiği ve takdir edip, haber verdiği konulara dair ilmin olduğunu ifade eder ve âhiret ehlinin dünyaya tekrar dönmesinin mümkün olmamasını buna misal verir. Bâkillânî, üçüncü kısmı ise şimdiki zamanımızda ma'dûm ma'lûm olmakla birlikte, ileride var olacak kıyamet, haşır ve neşir ile âhiret hayatı gibi hususlara ait bilgiler olarak açıklar. $\mathrm{O}$, dördüncü kısımda ise şu anda ma'dûm olup önceden var olan, geçmişte işlediğimiz fillerimizi ve tasarruflarımızı sayar. ${ }^{16}$

Mu'tezile genel manada ma'dûma şey denilebileceğini kabul etmekle birlikte onun özellikleri konusunda aralarında görüş birliği söz konusu değildir. Onlardan ma'dûmun şey ve cisim olduğunu kabul eden olduğu gibi, onun cisim değil de arazları kabul etmeye uygun bir cevher olduğunu söyleyenler de vardır. ${ }^{17}$ Bunların dışında ma'dûmun cisme ait bir kısım vasıflara sahip olduğunu kabul

13 Pezdevî, Usûlü'd-dîn, 214; Murat Akın, Basra ve Bağdat Mu'tezile Ekolleri (Şahıslar ve Görüş Ayrılıkları) (Ankara: Sonçağ Yayınları, 2017), 128

14 Eflatun, Diyaloglar II, trc. Ç. Naci Soykan, (İstanbul: Remzi Kitabevi, 1986), 334-5; Ebû Hamid Gazzâlî, Tehâfütü'lfelâsife, nşr. Süleyman Dünyâ (Kâhire: Dâru'l-Maârif, ts. ), 88.

15 Aristoteles, Metafizik, 97-100; Kalın, Varlık ve İdrak, 93; Yusuf Şevki Yavuz, "Adem", Türkiye Diyanet Vakfı İlâm Ansiklopedisi (İstanbul: TDV Yayınları, 1988), 1: 357.

16 Bâkıllânî, Kitâbü't-Temhîd, 34-5.

17 Kaya, Varlık ve Imkân,134-142. 
etmenin, cismin kadimliğini kabul etmek manasına geleceğini bunun da yaratıcı olan Allah'ın varlığını inkâra götüreceğini belirtenler de bulunmaktadır. ${ }^{18}$

Mu'tezile'nin ma'dûma şey dediğine dikkat çeken Mâtürîdî, onların Allah'ın sıfatları konusundaki görüşlerini tenkit eder ve tekvin ile mükevven arasındaki farklılığa dikkat çeker. ${ }^{19}$ Ebü'l-Yüsr Pezdevî ise, Mu'tezile'nin ilgili âyetleri delil getirerek ma'dûma "şey" denilebileceğini ve şey'in bilinip vasıflanabileceğini iddia ettiğini ancak bu lafızların mecaz olduğu belirtir ve ezelde Allah'ın dışında bir şeyin bulunmadığı konusunda ümmetin icma ettiğini belirtir. Pezdevî ayrıca Allah'ın dışında başka kadimleri kabul etmenin şirk olduğunu ifade eder. ${ }^{20}$

Ebu'l-Muîn en-Nesefî, Mu'tezile'nin ekserisinin "şey olmayandan (ademden) bir şeyin varlığının muhal olduğuna meylederek, Dehriyye'nin görüşünü doğruladıklarını belirtir ve onların eşyanın kadimliğini iddia ettiklerini söyler. O, Mu'tezile'nin "Âlem ma'dûmdur, ancak ma'dûm şeydir. Allah onu ademden yaratmıştır, fakat şey olmayanı (lâ şey'i), şey" yaparak değil, zira bu muhaldir" dediğini belirtir. Nesefî, Cübbâî ve Basra Mu'tezile'sinden bir topluğun, "vücûd halinde araz olanın, adem halinde de araz olduğunu" söyleyerek, cevher ve arazların ezelde mevcut olduğuna inandığını ifade eder. ${ }^{21}$

Şehristânî, Mu'tezile'nin felsefecilerin etkisi altında kaldıklarını ancak onların görüşlerini doğru bir şekilde anlamadan zihinde var olan tasavvurların a'yan olarak da sabit olduklarını zannederek ma'dûma şey dediklerini belirtir. O, Mu'tezile'nin ma'dûmu şey kabul etmesiyle, bazı felsefecilerin suret haline gelmeden heyûlânın varlığını kabul etmesi arasında ilişki kurar. ${ }^{22}$ Halbuki Şehristânî'nin de işaret ettiği $i^{23}$ gibi, Allah Teâlâ'nın ilminin ezelî olması, sonradan vücûd bulacak bir şeyin varlığının da ezelî olmasını gerektirmez ve ma'dûmun yok olduğu bilmek, onun varlık halinde bulunmasını gerekli kılmaz.

\subsection{Atom}

İlkçağ atomculuğunun kurucuları kabul edilen maddeci filozof Leukippos (M.Ö. 500-440) ve Demokritos (M.Ö. 460-370), âlemin bölünmeyen ve sonsuz olan parçacıkların (atom, cüz-i lâ yetecezzâ, cevher-i ferd) ayrılıp birleşmesi sonucunda meydana geldiğini söylemişlerdir. İlkçağ Grek atomculuğuna göre maddenin en son bölünmeyen parçası atom olup, onun öncesi ve sonrası yoktur. Demokritos'un bölünmeyen, üç boyutu olmayan dolayısıyla yer kaplamayan atom görüşünü esas alan bu anlayışa göre, yalnız atomlar ve boşluk var olup,

18 Ebû Mansûr Abdulkâhir el-Bağdâdî, el-Fark beyne'l-frak (Beyrut: Mektebetü İbn Sînâ,1990), 179; Ebü'l-Muzaffer el-i̇sferâyîni, et-Tebsîr fi'd-dîn, nşr. Kemal Yûsuf el-Hût (Beyrut: Âlemü'I-Kütüb, 1983), 84; Kaya, Varlık ve Imkân, 144-5.

19 Ebû Mansûr Muhammed el-Mâtürîdî, Kitâbü't-Tevhîd, nşr. Fethullah Huleyf (İskenderiye: y.y. ts.), 147-8.

20 Pezdevî, Usûlü'd-dîn, 215-6.

21 Nesefi, Tebsiratü'l-edille, I, 74-5

22 Şehristânî, Nihâyetü'l-ikdâm, 159, 165.

23 Şehristânî, Nihâyetü'l-ikdâm, 156-8. 
kâinattaki değişmeler, atomların mekanik tarzdaki birleşip ayrılmasından ibarettir. Dolayısıyla bu atomcu görüşe göre var olan bir şey yok olmaz ve yoktan da hiçbir şey var olmaz, her şey boşlukta hareket eden ve yukarıdan aşağıya düşen atomların tesadüfen birleşmesinin bir eseri olduğu için bu düşüncede Allah inancına yer verilmemiştir. ${ }^{24}$

İslâm dünyasında cüz-i lâ yetecezzâ düşüncesi, felsefe ile daha çok meşgul olan Mu'tezile önderlerinden Ebü'l-Hüzyl el-Allâf (ö.227/841) tarafından ilk defa ortaya konulmuş ise de onu kabul etmeyen Mu'tezile âlimleri de vardır. Meselâ Allâf ile muasır olan İbrahim en-Nazzam (ö.221/835), cismin sonsuz surette bölünebileceğine inanmıştır. ${ }^{25}$ Ehl-i sünnet kelamcılar ise bölünmez bir atomun (cüz-i lâ yetecezzâ, cevherin) varlığını genel olarak kabul etmekle birlikte atomun mekanik olan bir şey değil de Allah tarafından yoktan var edildiğini yani yaratıldığını söyleyerek, âlemin Allah’ın ilmi, iradesi ve kudreti dâhilinde var olduğunu ispata çalışmışlardır. ${ }^{26}$

İslam dünyasında atom düşüncesinin gelişmesine önemli katkısı bulunan Kâdı Ebû Bekir el-Bâkillânî, muhdesleri; müellef cisim, cevher ve araz olmak üzere üçe ayırarak ${ }^{27}$ atomun sınırsız ve sonsuz bir hareket içinde olduğunu ve yer kaplamadığını söyleyen İlkçağ atomcularından ayrılır. Eş'arî'nin el-cüz' ellezî lâ yetecezzâ konusundaki görüşleri hakkında geniş nakilde bulunan İbn Fürek ise, Eş'arî'nin âlemdeki cisimlerin parçalanmayan cüzlerden mürekkep olduğunu söylediğini ve eşyanın cüzlerinin parçalanmasının son bulacağını kabul etmeyenin ilhada giden kimse ile aynı olacağını ifade ettiğini belirtir. Ona göre cisimlerin muhdes olması nasıl anlaşılıyorsa, cüzlerin de mütenâhi (sonlu) olduğunu aynı şekilde anlaşıldığından, sonsuza kadar devam eden bir parçalanma olamaz. ${ }^{28}$

Abdülkerim Şehristânî (ö.548/1153), felsefecilerin heyûlâ anlayışından hareket ederek, onların cevher-i ferdi kabul etmelerinin geçersiz olduğunu ifade eder. Felsefecilerin cismin heyûlâ ve suretten meydana geldiğini söylediklerine dikkat çeken Şehristânî, onların heyûlâ ve suretin kadim olduğuna inanarak onlardan daha küçük parçadan bahsetmediklerini belirterek, filozofların aslında heyulâ ve suret olarak isimlendirdikleri şeyin cüz-i lâ yetecezzâ olduğuna işaret eder. ${ }^{29}$ Sa'düddîn Teftâzânî ise felsefecilerin cismin heyûlâ ve suretten terekküp etiğini inandıklarına işaret ederek, onların cüz-i lâ yetecezzâ (cevher-i ferd)yı

24 Eflatun, Diyaloglar II, 318; Aristoteles, Metafizik, 90, 306-312; Süleyman Hayri Bolay, Felsefi Doktrinler Sözlüğü (İstanbul: Ötüken Yayınları, 1981), 41.

25 Pezdevî, Usûlü'd-dîn, s. 11-8; Fahreddîn er-Râzî, el-Metâlibü'l-âliye mine'l-ilmi'l-ilâhî, nşr. Ahmed Hicâzî es-Sakâ (Beyrut: Dâru'I-Kitâbi'l-Arabî, 1987), 6: 20; İsmail Hakkı İzmirli, Yeni IIlm-i Kelam (İstanbul: Evkâf-ı İslâmiyye Matbaası, 1341), 1: 270-1.

26 Bâkıllânî, Kitâbü't-Temhîd, 37-43; Pezdevî, Usûlü'd-dîn, 11-8.

27 Kâdı Ebû Bekir el-Bâkıllânî, el-Insâf fîmâ yecibü i'tikâduh velâ yecûzü'l-cehl bih, nşr. M. Zâhid el-Kevserî, 2. Baskı (Kâhire: el-Mektebetü'l-Ezheriyye li't-Türâs, 1993), 15-6.

28 İbn Fûrek, Makâlâtu'ş-Şeyh Ebî'l-Hasen, 211.

29 Abdülkerîm Şehristânî, Mes'ele fî isbâti'l-cevheri'l-ferd, nşr. Alfred Guilaume (Nihâyetü'l-ikdâm'ın sonunda) (Kâhire: Mektebetü's-Sekâfeti'd-Dîniyye, 2009), 508. 
kabul etmediklerini belirtir ve cüz-i lâ yetecezzâ görüşünün tamam olması için heyûlâ ve suret görüşünün iptal edilmesi gerektiğini söyler. ${ }^{30}$

Günümüzde atom, kimyasal bir elamanın en küçük parçası şeklinde anlaşıldığından, bölünmezlik ve değişmezlik nitelikleri yerini bölünürlük ve değişirlik niteliklerine bırakmıştır. Atom çekirdeklerinin dönüşümü esnasında serbest kalan büyük enerji sebebiyle günümüzde atom düşüncesi geçmişe nispetle çok daha önem kazanmıştır. ${ }^{31}$ Tarihî maddecilik, gelişen bilimsel olaylar karşısında önemini kaybedip, madden çok kuvvet ön plana çıktığından yeni fizik ve kimya anlayışı atom düşüncesini tadil ederek kabul etmiştir. ${ }^{32}$

Geçtiğimiz asır, maddenin yapısına dair büyük keşiflerin gerçekleştiği bir dönem olmuş, yapılan araştırmalar atomun çekirdek ve etrafında dönen elektronlardan oluştuğu, çekirdeğin ise proton ve nötron adı verilen küçük parçacıkları ihtiva ettiği ortaya konulmuş, bu parçacıkların da daha çok daha küçük zerreciklerden meydan geldiği ifade edilmiştir. ${ }^{33}$ Sıkıştırılmış bir enerji deposu olan atomun yapısı hakkındaki bu gelişmeler onun süreksizliğini (bölünmenin bir noktada durması) savunan felsefî atomculuğu kazançlı çıkardığından bu gelişmenin, âlemdeki hareketi (var ve yok oluşları) sağlayanın evren dışında bir varlık (Allah) olduğu fikrini güçlendirdiği söylenmiştir. ${ }^{34}$

\subsection{Heyula}

Genel olarak "madde" kelimesiyle müteradif (eş anlamlı) kullanılan 35 "heyûlâ", eşyanın (âlemin) mahiyet veya hakikatini teşkil eden asıl cevher manasını ifade eder. ${ }^{36}$ Eski Yunan filozofları, âlemin yaratılışını izah ederken potansiyel bir güç ve bir imkân manasına gelen ve muayyen bir surete tahsis edilmeyen ancak, bir sureti kabul etmeye uygun maddeyi ifade eden heyûlâ lafzını anahtar bir kelime olarak kullanılmışlardır. ${ }^{37}$

Antikçağ Yunan filozofları arasında varlığın bir ilk özünün (heyûlâ) olduğunu kabul edenler bulunmakla birlikte heyûlânın kazandığı yaygın terim manası, hyl kelimesini icad ederek ona felsefi bir mana yükleyen Aristo'nun madde-suret teorisi sayesinde olmuştur. ${ }^{38}$ Aristo, âlemin heyûlâ denilen aslî cüzünün ezelî ve

30 Teftâzânî, Şerhu'l-Akâid, 50.

31 Hançerlioğlu, Felsefe Ansiklopedisi (Kavramlar ve Akımlar), 1: 196.

32 İzmirli, Yeni Illm-i Kelâm, 1: 271, 283.

33 Hüseyin Aydın, Yaratıış ve Gayelik, 7. Baskı (Ankara: Diyanet İşleri Başkanlığı Yayınları, 2012), 64.

34 Mehmet Bulğen, "Atomdan Kuantuma: Fizikteki Gelişmelerin Kelâma Etkisi”, Kader (Kelam Araştırmaları Dergisi), 11/1 (2013): 247-251.

35 Ebû Hamid el-Gazzâlî, Mi'yâru'I-ilim, nşr. Süleyman Dünyâ (Kâhire: Dâru'l-Maârif, 1961), 298.

36 Aristoteles, Metafizik, 90; Seyyid Şerîf Cürcânî, et-Ta'rifât, nşr. Abdurrahmân Umeyra (Beyrut: Matbaatü Mustafa, 1987), 112.

37 Eflatun, Diyaloglar II, 335 vd.; Aristoteles, Metafizik, 306 vd; Muhammed Ali b. Ali et-Tehânevî, “Heyûlâ", Keşşâfü Istılahâti'l-fünûn (Beyrut: Mektebetü Lübnân, ts.), 3: 1535; Fîrûzâbâdî, Ebü't-Tâhir, "Hyl", Kâmûs Tercemesi, trc. Âsım Efendi (i̇stanbul: y.y. 1305), 4: 163; Cürcânî, et-Ta'rifât, 314.

38 Hançerlioğlu, Felsefe Ansiklopedisi (Kavramlar ve Akımlar), 5: 53. 
ebedi olduğunu ileri sürerek, onun yaratılmış olduğunu inkâr etmiştir. Ona göre Allah, ilk maddeyi yaratmamış ona hareket ve şekil vermiştir. ${ }^{39}$ Aristo, heyûlânın tek başına fiilî bir varlığının olmadığını söyleyip, onu "tamamen belirsiz, cisme ârız olan değişmeyi kabul edici, kuvve halinde bir cevher" şeklinde tarif ederek, fiili varlığının maddede gerçekleşen suret olduğunu ifade etmiş̧tir. ${ }^{40}$

Heyûlâ konusu İslâm akâdinin temel konularından biri olmamakla birlikte felsefecilerin heyûlânın keyfiyetsiz ve kemiyetsiz mevcut olduğunu söylemeleri ve hâdis olduğuna alâmet alan hiçbir özelliğinin bulunmadığını ifade ederek, onun Allah'a mahsus olan kadim niteliğinin bulunduğunu söylemeleri, filozofların yanı sıra kelamcıların da bu meseleyle meşgul olmalarına yol açmıştır. İslâm dünyasında bu mesele etrafındaki tartışmalar filozof ve kelamcılarla sınırlı kalmamış, mutasavvıflar da meseleye kendi sahip oldukları bilgi birikimleriyle katılarak, konunun farklı açılardan ortaya konulmasını sağlamışlardır.

\section{VARLIK MESELESI ETRAFINDA ORTAYA ÇIKAN FARKLI GÖRÜŞLER}

\subsection{Filozoflar}

İslâm dünyasında Meşşâî olarak tanınan Fârâbî (ö.339/930) ve İbn Sînâ (ö.428/1037) gibi meşhur filozofların önderliğinde gelişen felsefi hareket, Aristo ve Eflatun gibi eski Yunan filozoflarının düşüncelerine ilgi duymaları sebebiyle onların varlık görüşlerinin de etkisinde kalmışlardır. ${ }^{41}$

Cismin heyûlâ ve suretten meydana geldiğini kabul eden İbn Sînâ; vücûdu, vâcibü'l-vücûd ve mümkinü'l-vücûd olmak üzere ikiye ayırır ve vâcibü'l-vücûd'un zâtıyla kâim, ortağı ve benzeri bulunmayan Hak (Allah) olduğunu ifade eder. O, vâcibü'I-vücûdun cins ve faslının olmadığı için tarifinin bulunmadığını belirtir ve vâcibü'l-vücûd'un mahiyeti itibariyle hiçbir şeye ortak olmadığını söyler. ${ }^{42}$

Fârabî, varlıkları (mevcûdât) hiyerarşik bir şekilde on dereceye ayırır ve on birinci derecede, cisimleşmemiş madde, soyut cevherler yer alır. Ona göre Allah'ın (ilk varlığın) dışındaki varlıklar, ilk mertebede mevcûd olan Allah'tan taşarak (feyezan) vücûd bulmuşlardır. On birinci derecede varlık bir madde olmamakla birlikte burada varlığı için maddeye ve mekâna ihtiyaç duymayan semavî varlık merhalesi sona ermiştir. Bundan sonra ateş, hava, su ve topraktan oluşan tabii cisimlerden bahseden Fârâbî, bu noktada Aristo'nun kullandığı madde-heyûlâ ve heyet- sûret kavramlarına yer vererek madde (heyûlâ) ve sûretten her birinin var olabilmek için diğerine muhtaç olduğunu ifade etmiştir. Dolayısıyla Fârâbî'nin sudûr görüşüne göre, madde olması itibariyle bir olan heyûlâ, faal aklın etkisiyle

39 Hilmi Ziya Ülken, Eski Yunan'dan Çağdaş Düşünceye Doğru İslam Felsefesi (İstanbul: Ülken Yayınları, 1993), 18.

40 Aydın, Yaratııı̧ ve Gayelik, 32-3.

41 Toshihiko İzutsu, İslâm'da Varlık Düşüncesi, trc. İbrahim Kalın (İstanbul: İnsan Yayınları, 1995), 115-120; Aydınlı, Fârâbî, 82-3.

İbn Sînâ, el-işârât ve't-tenbihât, 3: 19, 48-49. 
şekil ve suret kazanmış; su, toprak, ateş ve havanın birleşmesinden de cisim meydana gelmiştir.43

Kelamcıların ortaya koyduğu esaslara muhalif olmamaya çalışan İbn Sînâ, evcede, sanaa ve faale kelimelerinin bir şeyden, o anda olmayan bir şeyi meydana getirmek manasına geldiğine işaret eder. $\mathrm{O}$, bu kelimelerin manasından hareketle yokluktan varlığa çıkarmak için hareket ettirici veya tercih edici bir şeyin varlığının zorunlu olduğuna dikkat çekerek, varlığın yaratılmasında Allah'ın tesirine işaret eder. ${ }^{44}$ İbn Sînâ, âlemin yaratılmasını "ibdâ", "halk", "ihdas" ve "tekvin" kelimeleriyle ifade ederek, Allah'ın Yaratıcı, âlemin de yaratılmış olduğunu belirtir. ${ }^{45}$.....

\subsection{Kelamcilar}

İnsanların cevher konusunda farklı görüşlere sahip olduğuna işaret eden Ebu'lHasen el-Eş'arî, parçalanmayan bir cevherin (el-cevherü'l-vâhid ellezî lâ yünkasem) keyfiyeti hususunda ihtilaf olduğunu belirtir. ${ }^{46}$ Allah Teâlâ'nın mevcudiyetinin ezelî ve kadim olduğuna dikkat çektikten sonra Allah’ın bi-nefsihi (kendi zatıyla) mevcûd olduğunu ifade eden Eş'arî, diğer mevcûdâtın (varlıkların) ise bu vasıflara sahip olmayıp, var olmak için Allah'ın varlığına muhtaç olduğunu belirtir. ${ }^{47}$

İmam Ebû Mansûr Muhammed el-Mâtürîdî (ö.333/944), heyulâ konusunda öncelikle Aristo'nun görüşlerine atıfta bulunarak onun heyûlâyı uzunluğu, genişliği, mekânı, derinliği, rengi, kokusu, tadı, yumuşaklığı, sertliği, sıcaklığı, soğukluğu, sükûn veya hareketi olmayan, bir cevher kabul ettiğini belirtir. Mâtürîdî, heyulânın Aristo tarafından kendisiyle beraber hiçbir araz bulunmayan ve kendi tercihi olmadan arazların sonradan meydana gelmesiyle oluşan cevher şeklinde açıklandığını ifade eder. Bir kısım insanların âlemin kendisinden yaratıldığı (tînetü'l-âlem) ve kadim olduğu kabul edilen aslî maddeye "heyûlâ" diye isimlendirdiklerine ve heyulânın âlemin cevheri (cevher-i ferd) kabul edildiğine dikkat çeken ${ }^{48}$ Mâtürîdî, Allah'ın dışında bir varlığın kadim kabul edilmesinin yanlışlığına işaret eder.

Abdülkâhir el-Bağdâdî (ö.429/1036), Eş’arî́nin renk, oluş, tat ve kokundan arınmış bir cismin muhal olduğuna inandığını söyler ve heyûlâ ehlinin âlemin heyûlâsının ârazlardan hâli ve kadim bir şey olduğuna, ondan daha sonra ârazların meydan gelmesiyle âlemi oluştuğuna inandıklarını belirtir ve ârazlardan hâli olan bir heyûlânın bulunmasının imkansız olduğunu belirtir. ${ }^{49}$

\footnotetext{
Fârâbî, Ârâu ehli'l-medineti'l-fâzılâ, 17-27.

ìbn Sînâ, el-işârât ve't-tenbihât, 57-60.

Ülken, Eski Yunan'dan Çağdaş Düşünceye, 124.

Ebû'l-Hasen el-Eş'arî, Makâlâtü'l-İslâmiyyîn, nşr. M. Muhyiddîn Abdülhamid (Beyrut: el-Mektebetü'l-Asriyye, 1990), 2: 8-9.

4 İbn Fûrek, Makâlâtu'ş- Şeyh Ebî'l-Hasen, 43-4.

Mâtürîdî, Kitâbü't-Tevhîd, 147-8.

Ebû Mansûr Abdulkâhir el-Bağdâdî, Usûlu'd-dîn, 3. Baskı. (Beyrut: Dârü'l-Kütübi'I-IIlmiyye, 1981), 55-59.
} 
Felsefecilerin açıkladıkları şekilde bir heyûlâ olmadan âlemin Allah tarafından sonradan yaratılmış olduğunu söyleyen Bâkillânî, ma'dûm, ma'lûm ve vücûd konusunda sistematik açıklamalar yapar. $\mathrm{O}$, mevcudâtı, kadîm ve muhdes olarak ikiye ayırıp, âyân ve ârazdan terekküp eden cevher ve cismin hadis olduğunu söyleyerek, muhdesâtı yaratanın (muhdisin) Allah olduğuna dair aklî deliller getirir. O, bu çerçevede heyûlâya kısaca temas ederek; keyfiyet, kemiyet, suret ve bütün arazlardan hali olmuş bir heyûlâ ve tînetin muhal olduğunu belirtir. ${ }^{50}$

Fahreddin er-Râzî (ö.606/1210) ise, heyûlânın çeşitli manalara geldiğini belirterek, cisimlerin heyûlâsının olduğu hususunda akıl sahiplerini ittifak etiklerini, ancak heyûlânın mahiyeti konusunda ihtilaf düştüklerini belirterek, heyûlâya atfedilen mananın önemine işaret eder. "Biz cisimleri birbirine benzer maddede, ama değişik surette görürüz" diyen Râzî, bıçak ve kılıcın farklı şekil ve suretlerde olmakla birlikte asıl maddesinin (heyûlâsı) demir olduğunu söyler. ${ }^{51}$ Râzî, Aristo, Fârâbî, İ̉n Sinâ ve tâbilerinin hacim ve yer kaplamanın kendisiyle kâim bir zât olmayıp, bilakis heyûlânın bir sureti olduklarını ve suretlerin heyûlâya hulul etmesiyle de cisimlerin meydana geldiklerini kabul ettiklerini belirtir ve bu şekilde izah edilen heyûlânın batıl olduğunu söyler. ${ }^{52}$

Kelamcılar cismin, cüz-i lâ yetecezzâların telifinde meydana geldiğini söylerken Aristocu görüşü bağlı kalan İslâm filozofları cismin, heyûlâ ile suretten mürekkep olduğunu söylemişlerdir. ${ }^{53}$ Dolayısıyla filozoflara göre kâinattaki bütün cisimlerin aslî maddesini oluşturan heyûlâ ittisal ve infisalı kabul etme vasfına haizdir. Onlara göre suret, heyûlânın heyet ve kıyafeti olup, ona hulul etmiş yani heyûlâ mahal, suret hâl olmuştur. Onlar hem sureti hem de heyûlâyı ayrı ayrı birer ayın ve cevher kabul ettiklerinden cüz-i lâ yetecezzâ'nın varlığını imkansız görmüşlerdir. Dolayısıyla felsefecilere göre heyûlâ ve suret kadim olduğundan cisim de kadim olmaktadır. Ayrıca onlara göre suret bizatihi kâim olan bir cevher iken kelamcılara göre suret bir arazdır ve bizatihi kaim olmayıp cüz-i lâ yetecezzâ ile kaimdir. ${ }^{54}$

\subsection{Mutasavvıflar}

Kelamc kimliğinin yanında mutasavvıf kimliği ile de temayüz eden Ebû Hamid Gazzâlî (ö.505/1111), Mi'yâru'l-ilim isimli eserinde vücûdu on kısma, mevcûdu ise cevher ve a'raz olmak üzere iki kısma ayırır. ${ }^{55}$ Gazzâlî, madde ile heyûlânın müradif (eşanlamlı) olarak kullanıldığını belirtir ve adem ile zulmet, varlık ile nur arasında tam bir ilişki kurar ve varlığın veya heyûlânın ezelî olup, yok olmayacağına iddia eden filozofların görüşlerinin batıl olduğunu söyler. Var etmenin (i'câd) ve yok etmenin(i'dam) mutlak kudret sahibi Allah'ın iradesiyle olduğuna dikkat çeken

50 Bâkıllânî, Kitâbü't-Temhîd, 52.

51 Râzî, Metâlibü'l-âliye, 5: 5, 199.

52 Râzî, Metâlibü'l-âliye, 5: 199-200.

53 Şehristânî, Mes'ele fî isbâti'l-cevher, 503.

54 İzmirli, Yeni Illm-i Kelam, 1: 282-3.

55 Gazzâlî, Mi'yâru'l-ilim, 297, 303, 313. 
Gazzâlî, Allah'ın zatında bir değişiklik olmayıp, değişikliğin fiilde olduğunu söyler. O, fâilden (Allah'tan) fiilin sadır olmasını; "ondan sadır olan, yenilenen (teceddüt) şeydir ki o da yokluktur. Çünkü adem yok idi, sonra adem teceddüt etti" sözleriyle izah eder. Ademi bir nevi şer ve noksanlık olarak görmekle birlikte onun şey olmadığını kabul eden Gazzâlî, "fâilden bir şeyin sadır olması, sadece vuku bulan şeyin onun kudretine izafe edilmesi" diyerek sonradan meydana gelen bir şeyin yok olmasının da mümkün olduğuna dikkat çeker. ${ }^{56}$

Gerçek manada var olanın Allah olduğuna dikkat çeken Muhyiddîn İbnü'lArabî (ö.638/1240) ise, Allah Teâlâ'nın vücûd sıfatının vücubu'l-vücûd (vücûd zorunlu) olduğunu belirtir ve vücûdu; "aynî, zihnî, rakamî ve lafzî" olmak üzere dört kısma ayırır. Mutlak manada yokluğun hiçbir zaman vücûda (var olmaya) kabil olmadığını söyleyen ${ }^{57}$ İbnü'l-Arabî, mutlak manada ve hiçbir şekilde kayıtlanmayan vücûdun (var olma) Allah'a ait bir sıfat olduğunu ve Allah Teâlâ'nın kendi zatıyla kâim vâcibü'l-vücûd olduğunu belirtir. İbnü'l-Arabî, vâcibü'lvücûdun karşılığının ise adem-i mutlak (mutlak yokluk) olduğunu ve muhal olarak da isimlendirildiğine dikkat çeker. ${ }^{58}$

İbnü'l-Arabî, "Hiçbir şey yok ki onun hazineleri bizim yanımızda olmasın” (el-Hıcr, 15/21) âyetini zikrederek, Allah Teâlâ'nın eşyayı yarattığını ve ademden vücûda getirdiğini belirtir. O, Allah'ın hazinelerinden eşyayı çıkartmasını, "bizim anlamadığımız varlığın bizim anlayacağımız varlık haline getirme" şeklinde açıklar ve eşyanın adem-i sırftan değil de adem-i izâfîden zahir olduğunu söyler. İbnü'lArabî, "eşyaya adem halinde şahit olunur ve eşyanın hazineleri onun kaplarıdır ancak, eşya a'yânda vücûd bulmamakla birlikte sabittir"59 diyerek vücûd ile sübut arasında ayırım yapar. O da Gazzâlî gibi, ademi zulmet olarak açıklar ve mümkinâtın (âlem) a'yânını kendisinde nur bulunmayan ma'dûm olarak niteler ve onun sübut vasfını kazanmakla birlikte vücûd vasfını henüz kazanmadığını belirtip, vücûdun nur demek olduğunu hatırlatır. ${ }^{60}$

İbnü'l-Arabî, "Allah dilerse sizi giderir (ortadan kaldırır) ve başkalarını getirir" (en-Nisâ, 4/133) mealindeki âyette "sizi yok eder" manasına gelen "i'dam" kelimesinin değil de izhâb (gidermek) kelimesinin kullanılmasına dikkat çeker. İbnü'l-Arabî, "Allah Teâlâ, şey olanları giderendir (ortadan kaldıran, helak eden); ma'dumu, (olmayanı) değil" diyerek Allah'ın, fâil olduğunu fâilin ise bir şey yapan manasına geldiğini belirtir ve lâ şey (hiçlik)'in meful olamayacağını söyler. Ona göre "bir şeyi ortadan kaldırmak, başka bir yerde ona vücut vermek demektir. Zira ictima ve iftiraktan oluşan kevn, a'yânın yokluğuna delalet etmez. Ölüm bir

56 Gazzâlî, Tehâfütü'l-felâsife, 131, 169.

57 Muhyiddin İbnü'l-Arabî, el-Fütûhâtü'l-Mekkiyye, nşr. Ahmed Şemseddin (Beyrut: Dâru'I-kütübi'I-IImiyye, 1999), 3: $374,8: 46$.

58 İbnü'l-Arabî, Fütûhât, 3: 374; 5: 68 .

59 İbnü'l-Arabî, Fütûhât, 5: 286.

60 Muhyiddin İbnü'l-Arabî, Fusûsü'l-hikem, nşr. Ebu'l-Alâ Afîfî (Beyrut: Dârü'l-Kitâbi'l-Arabî,1946), 102. 
izhab (giderme, ortadan kaldırma) olup, i'dam (yok etme) değildir. Çünkü ölüm, dünyadan âhirete intikal etmektir."61

İbnü'l-Arabî'nin i'dam kelimesini bu şekilde açıklaması felsefecilerin görüşüyle benzerlik arz ettiğini söylenebilir. Zira filozoflara göre âlemin kadim olması sebebiyle madde de kadimdir olduğundan fâni olmak, terkibin zevali yani, mürekkebi meydana getiren cüzlerin dağılması manasına gelir. Kelamcılar ise fâni olmayı genel manada, i'dam (yok etmek) manasında kullanmışlardır. ${ }^{62}$ Fahreddin Râzî, “O'nun (Allah) zâtı hariç her şey helak olucudur" (el-Kasas, 28/88) âyetinin tefsirinde insanların bir kısmının helaki adem ile tefsir edip, Allah Teâlấnın zatının dışında her şeyi yok edeceğini söylediğini, bir kısmının da helaki, bir şeyi öldürmek veya cüzleri bâki olsa da onu parçalamak suretiyle kendisini menfaatinden çıkarmak şeklinde tefsir ettiklerini belirtir. Râzî, Allah'ın dışında her varlığın ademe (yokluğa) kabil olması sebebiyle helak olmaya da kâbil olduğunu ifade eder. ${ }^{63}$

İbnü'l-Arabî, Eş'arîlerin "adem halindeyken m’adûm şeydir" diyen insanları tenkit etmelerini doğru bulmaz ve onun adem halinde iken sâbit aynının olduğunu daha sonra o aynın vücûd bulduğunu ifade eder. ${ }^{64} \mathrm{O}$, ademi, muhal ve mümkün olmak üzere ikiye ayırır ve şöyle der: "Biz (insan) iki vasfı kabul eden bir hakikat üzereyiz. Biz vücuda nispetle ademe daha yakınız. Biz ma'dumuz, ancak muhal ile vasıflanmayıp imkan ile vasıflanırız. Biz ne vücuda ne de ademe karşı bir güce sahip değiliz. Ancak bizim için temayüz etmiş ayân-ı sabite vardır ve ona iki taraf itibariyle hitap vaki olur." ${ }^{65}$

İbnü'l-Arabî, "Allah vardı. Allah ile beraber hiçbir şey yoktu"66 hadis-i şerifini sıkça atıfta bulunur. ${ }^{67} \mathrm{O}$, hâdis olanların yaratılmasından sonra da Allah'ın önceden olduğu hal üzere bulunduğunu belirtip, Allah'ın sıfatında bir değişik olmadığı halde sonradan olanın (muhdes, hâdis) sıfatlarının değişken olduğuna işaret ederek, Allah'ın varlığı ile diğer varlıkları bir birinden ayırır. İbnü'l-Arabî, "şayet bir şey, Allah'ın varlığı ve sıfatlarında olduğu gibi öncesinde adem (yokluk) bulunmadan var olmuş ise buna kadim mevcûd, mâsivallah'ın varlığında olduğu gibi ademden meydana gelmiş ise buna muhdes mevcûd denir" ${ }^{\prime \prime 8}$ diyerek, Allah'ın varlığı ile mâsivanın varlığının farklı olduğunu ifade eder. ${ }^{69}$

Mâsivayı zatıyla ve fiiliyle anlaşılan olmak üzere ikiye ayıran İbnü'l-Arabî, Allah Teâlâ'nın hisle anlaşılan mahsusât gibi bizatihi anlaşılmaktan veya ma'kûl ve latif

61 İbnül'-Arabî, Fütûhât, 1: 511.

62 İzmirli, Yeni IIlm-i Kelam, 1: 277.

63 Fahreddîn er-Râzî, Mefâtihu'l-gayb (Beyrut: Dârü inyâi't-Türâsi'l-Arabiyye, 1981), 25: 24-5.

64 İbnü'l-Arabî, Fütûhât, 5: 69

65 İbnü'l-Arabî, el-Fütûhât, 3: 374

66 Buhârî, Bed'ü'l-halk, 1; Tevhîd, 22.

67 İbnül-Arabî, Fütûhât, 1: 69.

68 İbnü'l-Arabî, Fütûhât, 1: 183.

İbnü'l-Arabî, Fütûhât, 1: 184. 
varlıklarda olduğu gibi fiiliyle anlaşılmaktan münezzeh olduğunu ifade eder. O, "vücûd, Hakk'ın aynıdır" veya "Hakk'ın vücudundan başka bir şey yoktur"70 derken vücûd sıfatını, kendi zatıyla var olup, varlığı için başka bir şeye ihtiyaç duymayan, mutlak varlık manasında kullandığından vücûdun (var olanın) sadece "Allah", olduğunu belirtir. O, diğer varlıkların var olmak için Allah'a muhtaç olmalarını dikkate alarak, onlara "sonradan var olan ve Allah tarafından var edilen" manasına gelecek şekilde muhdes mevcut tabirini kullanarak, Allah'ın varlığının yanında diğer varlıkların yani âlemin varlığının âdeta görünmez olduğuna dikkat çeker. Allah Teâlâ'nın, mutlak vücûd sıfatıyla vasıflandığını belirten İbnü'l-Arabî, bu konudaki görüşünü şöyle ifade eder:

"Allah Teâlâ bir şey ile ma'lul veya illet değildir. O, zatıyla mevcut olup, O'nu bilmek varlığını bilmekten ibarettir. O'nun vücûd sıfatı zatının gayrı değildir. O'nun zatı bilinmemekle birlikte $O$, sıfatlarından kendisine nispet olunanla bilinir. O'nun zatının hakikatini bilmek memnudur. Bir delil ile veya aklî bir burhan ile bilinmez, tarif olunmaz. Çünkü Allah Teâlâ hiçbir şeye benzemez ve hiçbir şey de O'na benzemez. Senin O'na dair bilgin sadece "O'nun hiçbir şeye benzemediğidir." (eşŞûrâ, 42/11) Allah, sizi bu konuda tahzir eder. Allah'ın zatı hakkında düşünmekten men eden şerî ${ }^{71}$ delil varit olmuştur."72 Yukarıdaki ifadelerde görüldüğü gibi İbnü'l-Arabî, vücûd sıfatının Allah'ın zâtının gayrı olmadığını söyleyerek, "Allah'ın sıfatlarının zâtının ne aynı ne de ğayrı" olduğunu ifade eden Ehl-i sünnet'in görüşüne vücûd sıfatı konusunda katılmaz.

İbnü'l-Arabî, âyette (el-Furkân, 25/23; el-Vâkıa, 56/6) geçen hebâ73 kelimesi ile bütün tabiatların suretinde bulunan cevherin kastedildiğini söyler ve suretlerin ancak heba diye isimlendirilen cevherle var olduğunu ifade eder. Ona göre heba her suretin hakikatin olmakla beraber bölünmez, parçalanmaz ve bir noksanlıkla vasıflanmaz. O her beyazda bulunan beyazlık gibidir. ${ }^{74}$ İbnü'l-Arabî, "O'nun (Allah) nurunun temsili, sanki içinde lamba bulunan bir kandildir" (enNûr, 24/35) âyetinde Allah Teâlâ'nın, nurunu lambaya benzettiğine dikkat çeker ve $\mathrm{Hz}$. Muhammed'in, âlemin efendisi ve vücutta ilk zahir olan olduğunu belirtir. Ona göre Hz. Muhammed'in varlığı, bu ilahî nurdan, hebadan ve Hakikat-ı külliyeden meydana gelmiştir."75ibnü'l-Arabî, "Ölü iken hidayetle dirilttiğimiz ve kendisine nur verip, onunla insanlar arasında yürüyen kimse, karanlıklar içinde

70 İbnü'l-Arabî, Fütûhât, 4: 154, 169.

71 İbnü'l-Arabî, burada söz konusu delilin ne olduğu zikretmemekle birlikte bu delilin "Mahlukât hakkında tefekkür edin Allah (zâtı) hakkında tefekkür etmeyin" (İsmail b. Muhammed el-Aclûnî, Keşfü'l Hafâ' (Beyrut: Müessesetü Menâhili'l-İrfân, ts.), 1:311) şekilde rivayet olunun hadisin olması muhtemeldir.

72 İbnü'l-Arabî, el-Fütûhât, 1: 183.

73 Zemahşerî, âyette geçen hebâ kelimesinin: "Güneş ışığının pencereden içeriye girmesi esnasında odada ortaya çıkan toza benzer tanecikler" manasına geldiğini ifade eder. (Keşşâf, nşr. Âdil A. Abdulmevcûd- Ali M. Muavvız, (Riyad: Mektebetü'l-Ubeyd,1998), 4: 243); İmam Mâtürîdî ise hebâ'nın “ateş söndüğü zaman közün üzerinde kalan toz" manasına geldiğine dikkat çektikten sonra, hebânın "lâ şey" yani hiçlik manasına geldiğini belirtir. (Te'vîlâtü Ehli's-sünne, nşr. Fatıma Yusuf el-Hıyamî (Beyrut: Müessesetü'r-Risâle, 2004), 3: 500).

74 İbnü'l-Arabî, Fütûhât, 1: 188.

75 İbnü'l-Arabî, Fütûhât, 1: 184. 
kalıp, ondan çıkamayan kimse gibi olur mu?" (el-En'âm, 6/122) âyetini zikrederek, "Hakk'ın vücûdundan başka vücûd yoktur, o da nurdur" der. O "Allah bir kulunu sevdiği zaman onun işiten kulağı, yürüyen ayağı olur" ${ }^{\prime \prime 7}$ şeklindeki hadis-i kudsîyi hatırlatarak, verilen nur sebebiyle kulun, âdeta Rabbi ile işitip yürüdüğünü belirtir. İbnü'l-Arabî, güneş ay, yıldız, lamba ve ateşte olduğu gibi nurun farklı derecelerinin bulunduğunu belirtir ve bu mertebelerine göre anlaşılıp, ifade edildiğini söyler. ${ }^{77}$

Bazı filozof ve mutasavvıfların vücud/varlık konusundaki görüşlerine ciddi tenkitler getiren İmâm-ı Rabbânî (ö.1034/1624), heyûlânın varlığını veya yokluğunu kabul etmekten ziyade ona atfedilen mananın önemli olduğuna işaret eder ve âlemin Allah'ın iradesiyle ve kudretiyle sonradan yaratılmış olduğunu açık bir şekilde ifade eder. $\mathrm{O}$, bir kısım düşünürlerin eşyanın oluş veya fesadı esnasında suretlerin değişmesiyle birlikte heyûlanın değişmediğine inanarak onun bâki (ezelî) olduğunu kabul ettiklerine dikkat çeker ve bu düşüncenin, Allah'ın dışında başka bâkinin varlığının kabulü manasına geleceğinden İslâm itikadı açısından yanlış olduğunu belirtir. İmâm-ı Rabbânî, Allah'ın kadîm olduğu ve Allah'ın dışında kadîm ve ezelînin bulunmadığı hususunda bütün din mensuplarının ittifak etmelerine karşın Fârâbî ve İbn Sînâ gibi filozofların ukûl, nüfûs, heyûlâ ve suretin kadim olduğunu söylemeleri sebebiyle Gazzâlî tarafından tekfir edildiklerini hatırlatır. ${ }^{78}$

İmâm-ı Rabbânî, kelamcıların "zatının ne aynıdır ne de gayrıdır"sözünün Allah Teâlấnın kadîm sıfatları konusunda doğru olduğunu ancak, bunun âlem hakkında doğrudan uzak olduğunu belirtir ve Allah ile âlemin, Hâlık ile mahlûkun tamamen ayrı iki varlık olarak ispat edilmesi gerektiğini ifade eder. ${ }^{79}$ İmâm-ı Rabbânî, fena ve bekânın Kadir ve Muhtar (istediği her şeyi yapmaya gücü bulunan) olan Allah'ın i'dam (yok etme) ve i'câdıyla (varlık haline getirme) olduğunu belirtir. O, âlemdeki var oluş ve yok oluşun kendiliğinden değil de Allah iradesi ve gücüyle olduğuna vurgu yaparak ${ }^{80}$ bir kısım filozoflar tarafından ileri sürülen "âleme bir tesiri olmayan ilah inancını" reddeder.

İmâm-ı Rabbânî, Allah Teâlâ'nın sıfatları ve isimleri için ilmî suretlerin akisleri (yansımaları) olmakla birlikte ademlerin her türlü şer ve noksanlığın kaynağı olduğunu belirtir. O, söz konusu ademleri heyûlâya, akisleri de ona hulul etmiş suretlere benzeterek, zahir olan akisler ile ademlerin, temayüz edip varlık kazandığını ifade ederek, âlemin sonradan yaratılmış olduğuna işaret eder. İmâm-ı Rabbânî, ademlerle temayüz etmiş akislerin oluşumunun, cevherle arazın oluşması gibi olmayıp, heyûlâ ile suretlerin oluşması gibi olduğu söyler. ${ }^{81}$

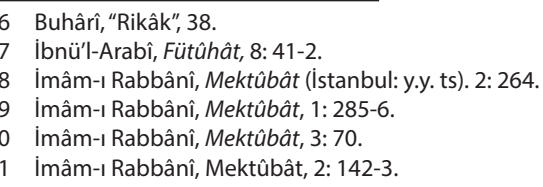


Gerçek manada vücûdu sadece Allah'ın bir sıfatı olarak gören İmâm-ı Rabbânî, HakTeâlâ'nın hakikatini vücûd-ı sırf tabiriyle açıklar ve bu hususta O'na hiçbir şeyin asla mülhak olmadığı belirtir. O, Allah'ın hakikati olarak açıkladığı vücûdu sırfın bütün hayır ve kemâlâtın menşei, her güzellik ve cemâlin mebdei, ademin ise her türlü şer ve noksanlığın kaynağı olduğunu ifade eder ve vücûd-ı sırfın hakikat itibariyle tasavvurunun memnu olduğuna dikkat çekerek, onun zihnî ve haricî olarak terkip etmediğini belirtir. ${ }^{82}$ Eşyanın zıddıyla anlaşılacağına işaret ederek, vücûd-ı sırfın mukabilinin adem-i sırf olduğunu söyleyen İmâm-ı Rabbânî, ademin harice itibarla lâ şey-i mahz olduğunu belirtmekle birlikte ilimde kendisi için imtiyaz arız olmasıyla vücûd-ı ilmînin ve vücûd zihnînin hasıl olduğunu ifade eder. ${ }^{83}$

İmâm-ı Rabbânî'ye göre adem, lâ şey (hiçlik) olmakla birlikte yokluk aynasındaki yansımalar olması itibariyle ilmen sabit olduğu gibi, ilim sahasının dışında da ayrıca vehmî mertebede de sabittir. Ademin sübutu ile vücûdu (varlığı) arasında ayırım yapan İmâm-ı Rabbânî'ye göre ademin vücûd-ı haricîsi (dış dünyadaki varlığı) olmadan önce birisi ilim diğeri de vehim mertebesinde olmak üzere iki sübutu vardır ve ademi bu şekilde sabit kılan Allah Teâlâ'dır. ${ }^{84}$ İmâm-ı Rabbânî'ye göre, ilim sahasında sabit olan ademler, Allah'ın iradesiyle vücûd-ı zıllî (gölge varlık) ile vasıflanmış bir mahiyet kazanıp, vücûd-ı haricî olarak yaratılmıştır. ${ }^{85}$

İmâm-ı Rabbânî, mahlukâtın Allah'tan sudûr ettiğini açıklayan zahiri ulemânın anlayışlarını noksan bulur ve onların âlemin varlığının gerçek olduğunu kabul ettiklerine dikkat çektikten sonra âlemin gölge olarak var olduğunu belirtir. Zira İmâm-ı Rabbânî ve onun gibi düşünen mutasavvıflara göre Allah ile âlem arasındaki ilişki, asıl ile gölge arasındaki ilişkiye benzer. Bir başka ifadeyle sûfiyye göre Hak Teâlâ'dan sadır olan âlem, her şeyden münezzeh olan Allah'ın kemâlatından neşet eden bir gölge ve akistir. ${ }^{86}$ İmâm-ı Rabbânî, bu açıklamalarıyla âleme gerçek manada vücûd vasfı veren kelamcılardan ayrıldığı gibi âlemi, vehim ve gölge olarak gören ancak gölge ve yansımayı bir varlık olarak kabul etmeyen İbnü'l-Arabî ve onun gibi vahdet-i vücûd anlayışına sahip diğer mutasavvıflardan da ayrılır. Vahdet-i vücutçu bir kısım insanların şeriata uymayan düşüncelerine karşın vahdet-i şuhûd anlayışını geliş̧iren İmâm-ı Rabbânî, bir sâlikin sahiv (manevi uyanıklık) haline geçip bekâ makamına ulaşmasından sonra vahdet-i vücûd düşüncesinin kaybolacağını ve vahdet-i şühûdun tecelli edeceğini belirtir. ${ }^{87}$

82 İmâm-ı Rabbânî, Mektûbât, 1: 209.

83 İmâm-ı Rabbânî, Mektûbât, 1: 215-6.

84 İmâm-ı Rabbânî, Mektûbât, 2: 161.

85 İmâm-ı Rabbânî, Mektûbât, 2: 6, 2: 74.

86 İmâm-ı Rabbânî, Mektûbât, 3: 118, 3: 105.

87 İmâm-ı Rabbânî, Mektûbât, 1: 13. 
İmâm-ı Rabbânî, âlemin hariçteki varlığının zıllî (gölge) bir varlık, Allah'ın varlığını ise aslî olduğunu söyleyerek "bir şeyin gölgesinin o şeyin aslı olmadığını belirtir ve "âlem Allah'ın aynısıdır demek mümkün değil" der. O, "birisi, bir şahsın aslı ile gölgesinin aynı olduğunu söylerse bunun mecaz bir ifade olduğunu" ifade eder ve vahdet-i vücûd anlayışının gölgeye hariçte bir varlık ispat etmeyip, mevcudu tek gördüğünü, kendisine göre ise gölgenin de gölge olarak bir varlığının bulunduğunu ifade eder. İmâm-ı Rabbânî, vücûd-i aslî ile var olan Allah'tan gölgeyi nefyetmek ve gölgenin varlığını ispat etmek konusunda vahdet-i vücûd görüşünde olanlarla aynı düşünmekle birlikte gölgenin sadece vehimde var olduğunu söylemeleri hususunda onlardan ayrılmakta ve gölgenin haricî varlığını kabul etmektedir.

Âlem konusu izah ederken "Allah, semavât ve arzın nurudur" (en-Nûr, 24/35) âyetini esas alan İmâm-ı Rabbânî, "semavât ve arzın nuru Hak Teâlâ'dır" demekle birlikte âlem ile Allah'ın nuru arasındaki farka dikkat çeker. O, Âlem-i kebirin en şerefli cüzünün, Allah Teâlâ'nın sıfatlarının hepsini cem edici olan Hazreti'z-zât'ın nurlarının zuhur mahalli bulunan Arş-ı a'lâ olduğunu belirtir ve onun dışındaki zuhurâtın zılliyet (gölge) şâibesinden (noksanlık) hali olmadığını ifade eder. Gölgelerden hiç birinin hakikatte Allah Teâlâ'nın tezâhürü olmadığına dikkat çekerek, âlemin Allah kabul edilmesi gibi yanlış bir anlayışın önüne geçen İmâm-ı Rabbânî, âlemin Allah'ın nuru olmakla birlikte bu nurun gölgelerle perdelendiğini söyler ve zılliyetin tavassutu olmaksızın Allah'ın nurunun tezahür etmediğini açıklar. ${ }^{88}$

Buraya kadar yaptığımız açıklamalardan anlaşılacağı üzere mutasavvıfların Allah-âlem ilişkisini açıklarken vücûd ve adem kelimeleri etrafında ortaya koydukları görüşler, pek çok noktada felsefe ve kelamcılarından farklılık arz etmektedir. Bununla birlikte çağımızda maddenin, elektrik enerjisinden ibaret olan atomlar olarak görülmesi ve âlemin aslını teşkil eden atomların enerjiden ibaret olduğunun söylenmesi, âlemin aslının nur olduğunu ifade eden mutasavvıfların görüşlerinin önemine işaret etmektedir.

\section{VARLIK HAKKINDAKI FARKLI GÖRÜŞLERIN ITIKADÎ BOYUTU}

Kelamcılar, atomun başlangıcı ve sonu olan, bir mekân işgal eden, varlığı zorunlu olmaması itibariyle yok olması da mümkün olan varlıklar olarak kabul ederek onu Allah'a mahsus olan hiç bir sıfatla açıklamamışlardır. ${ }^{89}$ Onlar, âlemi oluşturan atomların (cüz-i lâ yetecezzâ veya cevher-i ferd) Allah tarafından ve sonradan yaratıldığını açık bir şekilde ifade etmişlerdir. Heyulâ meselesi asıl itibariyle itikatla alakalı olmadığından dolaylı yoldan heyûlâ konusuna girmek durumunda kalan kelamcılar, cüz-i lâ yetecezzâ (bölünmez cevher) anlayışına dinî bir karakter kazandırmışlardır. Kelamcılar, felsefecilerin iddia ettikleri şekildeki

88 İmâm-ı Rabbânî, Mektûbât, 1: 19.

89 Eş'arî, Makâlâtü'l-Islâmiyyîn, 2: 8-9; Mâtürîdî, Kitâbü't-Tevhîd, 147-8; İbn Fûrek, Makâlâtu'ş- Şeyh Ebî'l-Hasen, $43-4$. 
bir heyûlâ düşüncesini; "Allah Teâlâ'nın Mutlak Yaratıcı ve sadece Allah'ın kadim olduğu esasına ve "Allah vardı. Allah ile beraber hiçbir şey yoktu"90 hadisiyle ifade edilen gerçeğe muhalif bularak heyulâ hakkında böyle bir inancın küfür olduğunu ifade etmişlerdir. ${ }^{91}$ Heyûlânın kendi kendine var olma özelliğinin olduğuna inanılması, âlemin Allah tarafından yaratıldığı inancına da ters düşmektedir. Bu hüküm heyûlânın ezelî bir madde olarak kabul edilmesi durumunda ortaya çıktığı gibi ma'dûm'un (yokluğun) bir varlık gibi görülmesi durumunda da ortaya çıkabilmektedir.

Kelamcılar, İslâm akâidini çeşitli delillerle izah etmeye çalışırken maddenin vücûd-ı hâricîyesisini kabul edenler arasında yer almışlardır. ${ }^{92}$ Ancak onlar, cisimlerden oluşan âlemin a'râz (arazlar) ve a'yândan (ayınlar, cevherler) terekküp ettiğini söyleyerek her hâdise bir muhdisin lazım geldiğini ifade etmişler ve varlığı zorunlu bulunan muhdisin Allah olduğunu belirtmişlerdir. Dolayısıyla onlar, filozofların iddia ettiği vasıflara sahip bir heyulâ (madde)yı reddetmekle birlikte atomun varlığını kabul etmiş̧ler, fakat onun kadim olmayıp, hâdis olduğunu ve muhdisin de Allah olduğunu ispata çalışarak filozoflardan ayrılmışlardır.

İmam Mâtürîdî, tevhid ehlinin Allah Teâlâ'yı filozofların heyûlâya verdikleri vasıflarla tavsif ettiğini hatırlatmış ve böyle söyleyen insanların sözlerinin nereye ulaştığını düşünmediklerinden tenakuza düştüklerini ifade etmiştir. Mâtürîdî, bir şeyin kendiliğinden meydana gelmesinin mümkün olmadığına işaret ederek, âyan ve ârazlardan teşekkül eden cevher veya heyulânın sonradan yaratıldığını, dolayısıyla kadim vasfı taşımalarının mümkün olmadığını söylemiştir. ${ }^{93}$

Eş'arî'nin görüşlerini aktaran İbn Fûrek, tevhitte asıl olan kaidelerden birisinin cevher ve arazlardan oluşan âlemin tek olan Allah tarafından yoktan yaratıldığının kabul edilmesi olduğu söylemiş ve bunun dışında bir inancın Allah Teâlâ'ya şirk olacağını belirtmiştir. ${ }^{94}$ Eş'arî kelamcısı Bâkillânî ise âlemin müellef cisimden veya münferit cevherden, ya da başkasında ortaya çıkan arazlardan meydan gelmesi sebebiyle muhdes olduğunu söyleyip, muhdesi yaratanın Allah olduğunu ifade etmiştir. ${ }^{95}$

Mâtürîdî kelamcısı Pezdevî ise, Ehl-i kıble'nin ve dinlere mensup olanların büyük çoğunluğunun Allah Teâlâ'nın âlemi bir asıl(heyûlâ) olmadan yarattığını kabul ettiklerini ifade ederek, Allah'ın dışında heyûlâ veya başka bir kâdimin bulunmasının imkansız olduğunu belirtir. ${ }^{96}$ Pezdevî, "Bir şeyden bir şeyi yaratmak, o şeyi değiştirmek, toplanmış olan bir şeyi ayırmak ve ayrı olan bir şeyi bir araya

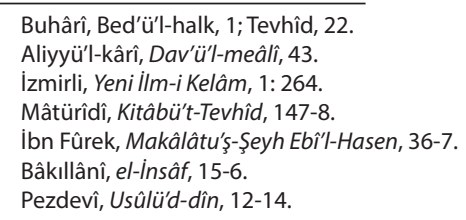


getirmektir. (Yaratmak)Ya bir şeyden bir şeyi çıkarmak veya da ağaçtan koltuk ve yünden keçe yapmak gibi bir şeyden bir şeyi icat etmektir" diyerek felsefecilere göre heyûlânın bu özellikleri kabul etmedikleri halde âlemin ondan yaratıldığını iddia etmelerinin tutarsız olduğunu belirtir. ${ }^{97}$ Bir kısım insanların heyûlâyı tevhid ehlinin Allah Teâlâ'yı vasıfladığı şekilde tavsif ettiğine dikkat çeken Ebu'l-Muîn en-Nesefi ise, heyûlâ ehlini, arazların bir yaratıcı (Sâni') tarafından meydana getirilmediğine inanan ve heyûlânın dışında bir yaratıcı ve kadîm kabul etmeyen kimseler olarak açıklamıştır. ${ }^{98}$

Râzî, parçalanmayan bir cüzün (el-cüz' ellezî lâ yetecezzâ,) varlığını kabul edenlerin cisimlerin bundan meydana geldiğine inandıklarını belirterek, cisim ve cevherlerin hâdis olduğunu söyleyenlerin ise bu cevherleri Allah'ın yarattığını kabul ettiklerini ifade eder. Cüzlerin kadim olduğuna inanların bir kısmının, ezelde boşlukta dağınık bulunan cüzlerin Allah tarafından bir araya getirilerek âlemin yaratıldığına inandıklarına dikkat çeken Râzî, bir kısmının ise "cüzler toplu halde iken Allah Teâlâ onları birbirinde ayırıp, bazısını felek, bazısını da ateş ve hava gibi şeyler olarak yarattığını" kabul ettiklerini belirtir. ${ }^{99}$ Râzî, "Kâfirler görmezler mi ki; gökler ve yer bitişikken biz onları ayırdık" (el-Enbiyâ, 21/30) âyetini buna delil gösterir.

Bağdâdî, heyulâ ehlinin; heyûlânın kadîm olup, onun arazlarının hadis olduğunu söylediğini, ayrıca farklı görüş sahiplerinin de Allah'tan başka kadimlerin olduğuna inandığına dikkat çektikten sonra hak ehlinin bütün cisim ve arazların muhdes olduğunu kabul ettiklerini belirtir. ${ }^{100}$ Teftâzânî ise, el-cüz' ellezî lâ yetecezzânın varlığını kabul etmenin; heyulâ ve suretin kadim olduğunu söyleyerek âlemin kadim olduğuna inanan ve haşr-i cismânîyi inkâr eden felsefecilerin iddiasını geçersiz kılma konusunda faydalı olduğunu belirtir. ${ }^{101}$

Kelamcılar heyûlâ meselesi gibi parçalanmayan bir cüzü yani el-cüz' ellezî lâ yetecezzânın (atom) varlığını kabul etmeyi, İslâm akaidinin zorunlu esaslarından bir esas görmemişlerdir. ${ }^{102}$ Bununla birlikte onların çoğu, Allah'ın varlığını ispat sadedinde, âlemin hâdis olduğunu göstermek etmek için onun (maddenin) sonsuz kadar parçalanmasının devam etmeyip, bir noktada parçalanmayan en son bir cüzünün olduğunu kabul etmişlerdir. Kelamcılar, arazların var olmaları için bir başka şeye (a'yan, cevher) muhtaç olduklarını, aynı şekilde cevherin de arazsız var olmasının mümkün olmadığını söylemişler ve ayan ve arazdan meydana gelen cismin muhdes olduğunu (sonradan meydana geldiğini) dikkat çekmişledir. Kelamcılar cisimlerden meydan gelen âlemin kendiliğinden var

97 Pezdevî, Usûlü'd-dîn, 16.

98 Nesefi, Tebsıratu'l-edille, 1: 59.

99 Râzî, el-Metâlibü'l-âliye, 6: 5, 199.

100 Bağdâdî, Usûlü'd-dîn, 59.

101 Teftâzânî, Şerhu'l-Akâid, 46-5.

102 Aliyyü'l-kârî, Dav'ü'l-meâlî, 8. 
olmasının mümkün olmadığını belirterek, âlemin vâcibü'l-vücûd (varlığı zorunlu) olan Allah tarafından yaratıldığını ispata çalışmışlardır. ${ }^{103}$

Allah'a ait olan kıdem gibi bazı sıfatların heyulâya verilmesi, İslâm itikadının temel unsurlarından olan "Allah'ın dışındaki hiçbir varlığın ezelî olmadığı, yani Allah'ın dışında her şeyin evvelinde yokluğun bulunduğu ve sonradan yaratılmış olduğu" esasını ortadan kaldırmaktadır. ${ }^{104}$

\section{Sonuç}

Aristo'nun "tamamen belirsiz ve kuvve halinde ezelî bir cevher" olarak kabul ettiği heyûlâ anlayışına karşılık, İslâm dünyasında heyûlânın varlığından çok ona atfedilen vasıfların geçersizliğine dikkat çekilmiştir. Yunan atomculuğu, yaratmayı ve bir yaratıcıyı kabul etmeyip, atomların sonsuz sayıda ve ezelî olduklarını söylerken kelamcılar, atomların (cüz-i lâ yetecezzâ veya cevher-i ferd) Allah tarafından yaratılan, başlangıcı ve sonu olan, varlığı zorunlu olmaması itibariyle yok olması da mümkün olan varlıklar olarak görmüşlerdir. Allah'a ait olan bazı sıfatların heyûlâya verilmesi, kelamcılar tarafından İslâm itikadının temel unsurlarından olan "Allah'ın dışındaki hiçbir varlığın ezelî olmadığı ve âlemin sonradan yaratılmış olduğu" esasıyla çelişkili bulunup, reddedilmiştir.

Yunan filozoflarının atom düşüncesine büyük ilgi gösteren Mu'tezile genel manada ma'duma şey denilmesini caiz görerek zımnen cismin de kadimliğini kabul etmek gibi sakıncalı bir durumla karşı karşıya kalmıştır. Ehl-i sünnet kelamcılar ise atomun (cüz-i lâ yetecezzâ, cevherin) varlığını genel olarak kabul etmekle birlikte atomun mekanik olarak değil de Allah tarafından yaratıldığını söyleyerek âlemin yoktan (şey olmayan) Allah’ın ilmi, iradesi ve kudreti dâhilinde var olduğunu ispata çalışmışlardır.

Mutasavvıflar ise Allah-âlem ilişkisini açıklarken âlemin mutlak yokluktan (adem-i mahz) değil de nurdan yaratılmış olduğunu söyleyerek bu konuda felsefe ve kelamcılarından farklı biz izah getirmişlerdir. Çağımızdaki bazı fizikçilerin; maddeyi elektrik enerjisi yüklü olan atomlar olarak açıklanması, mutasavvıfların âlemin aslının nur olduğunu görüşünü teyit eden bir özellik taşıdığı söylenebilir.

103 İmâmu'l-Haremeyn el-Cüveynî, el-Irşâd ilâ kavâtı'ı'l-edille fî usûli'l'-i'tikâd, nşr. Esad Temimî (Beyrut: Müessetü'lKütübi's-Sekâfiyye, 1992), 39-42; Teftâzânî, Şerhu'l-Akâid, 46-50.

104 Nesefi, Tebsiratü'l-edille, 1: 77. 


\section{KAYNAKÇA}

Aclûnî, İsmail b. Muhammed. Keşfü'l Hafâ'. Beyrut: Müessesetü Menâhili'l-İrfân, ts.

Akın, Murat. Basra ve Bağdat Mu'tezile Ekolleri (Şahıslar ve Görüş Ayrılıkları). Ankara: Sonçağ Yayınları, 2017.

Aliyyü'l-kârî. Dav'ü'l-meâlî fî şerhi Bed'i'l-Emâlî. İstanbul: y.y. ts.

Aristoteles. Metafizik. Trc. Ahmet Aslan, İstanbul: Sosyal Yayınları, 1985.

Aydın, Hüseyin. Yaratııı̧ ve Gayelik. 7. Baskı. Ankara: Diyanet İşıleri Başkanlığı Yayınları, 2012. Aydınlı, Yaşar. Fârâbî, İstanbul: TDV Yayınları, 2017.

Bağdâdî, Abdulkâhir Ebû Mansûr. el-Fark beyne'l-frak. Beyrut: Mektebetü İbn Sînâ, 1990.

Bağdâdî, Abdulkâhir Ebû Mansûr. Usûlu'd-dîn. 3. Baskı. Beyrut: Dâru'l-Kütübi'I-ilmiyye, 1981.

Bâkıllânî, Kâdı Ebû Bekir. Kitâbü't-Temhîd. nşr. Imâdüddîn A. Haydâr. Beyrut: Müessetü'lKütübi's-Sekâfiyye, 1987.

Bâkıllânî, Kâdı Ebû Bekir. el-Insâf fìmâ yecibü i'tikâduh .... nşr. M. Zâhid el-Kevserî. 2. Baskı. Kâhire: el-Mektebetü'l-Ezheriyye li't-Türâs, 1993.

Bolay, S. Hayri. Felsefi Doktrinler Sözlüğü. İstanbul: Ötüken Yayınları, 1981.

Bulğen, Mehmet. "Atomdan Kuantuma: Fizikteki Gelişmelerin Kelâma Etkisi". Kader (Kelam Araştırmaları Dergisi) XI/1 (2013): 247-251.

Cürcânî, Seyyid Şerîf. et-Ta'rifât. nşr. Abdurrahmân Umeyra. Beyrut: Matbaatü Mustafa, 1987.

Cüveynî, Ebû'l- Meâli. el-îrşâd ilâ kavâtı'ı'l-edille, nşr. Esad Temimî. 2. Baskı. Beyrut: Müessetü'l-Kütübi's-Sekâfiyye, 1992.

Eflatun. Diyaloglar II. Trc. Ç. Naci Soykan, İstanbul: Remzi Kitabevi, 1986.

Eş'arî, Ebû'l-Hasen. Makâlâtü'l-İslâmiyyîn. nşr. M. Muhyiddîn Abdülhamid. Beyrut: elMektebetü'l-Asriyye, 1990.

Fârâbî, Ebû Nasr Muhammed. Ârâu ehli'l-medineti'l-fâzılâ, Kâhire: Matbaatü's-Saâde, 1906.

Fîrûzâbâdî, Ebü't-Tâhir. "Hyl", Kâmûs Tercemesi. trc. Âsım Efendi. İstanbul: y.y. 1305.

Gazzâlî, Ebû Hamid. Mi'yâru'l-ilim. nşr. Süleyman Dünyâ. Kâhire: Dâru'l-Maarif, 1961.

Gazzâlî, Ebû Hamid. Tehâfütü'l-felâsife. nşr. Süleyman Dünyâ. Kâhire: Dâru'l-Maârif, ts.

Hançerlioğlu, Orhan. Felsefe Ansiklopedisi (Kavramlar ve Akımlar). İstanbul: Remzi Kitabevi, 1978.

İbn Fûrek, Ebû Bekr Muhammed. (Mücerredü) Makâlâtu'ş- Şeyh Ebî'l-Hasen el-Eşa'rî. nşr. Ahmed Abdurrahîm es-Sâyah. Kâhire: Mektebetü's-Sekâfeti'd-Dîniyye, 2005.

İbn Sînâ, Hüseyin b. Abdullah. el-İsârât ve't-tenbihât. nşr. Süleyman Dünyâ. 3. Baskı, Kâhire: Dârü'l-Maarif, 1985.

İbnü'l-Arabî, Muhyiddin. el-Fütûhâtü'l-Mekkiyye, nşr. Ahmed Şemseddin. Beyrut: Dâru'lKütübi'l-IIlmiyye, 1999.

İbnü'l-Arabî, Muhyiddin. Fusûsü'l-hikem. nşr. Ebu'l-Alâ Afîfî. Beyrut: Dârü'l-Kitâbi'l-Arabî, 1946. 
İmâm-ı Rabbânî. Mektûbât. İstanbul: y.y. ts.

İsferâyîni, Ebü'l-Muzaffer. et-Tebsîr fi'd-dîn. nşr. Kemal Yûsuf el-Hût. Beyrut: Âlemü'l-Kütüb, 1983.

İzmirli, İsmail Hakkı. Yeni İlm-i Kelâm. İstanbul: Evkâf-ı İslâmiyye Matbaası, 1341.

İzutsu, Toshihiko. İslâm'da Varlık Düşüncesi. Trc. İbrahim Kalın, İstanbul: İnsan Yayınları,1995.

Kâdı Abdulcebbâr. Şerhu'I-Usûli'l-hamse. nşr. Ahmed b. el-Hüseyn. Beyrut: Dâru İhyâi'tTürâsi'l-Arabî, 2001.

Kalın, İbrahim. Varlık ve Idrak Molla Sadrấnın Bilgi Tasavvuru, çev. Nurullah Koltaş, İstanbul: Klasik 2017.

Karadeniz, Osman. “Heyûlâ". Türkiye Diyanet Vakfı Islam Ansiklopedisi. 17: 294. İstanbul:TDV Yayınları, 1998.

Kaya, M. Cüneyt. Varlık ve Imkân Aristoteles'ten İbn Sînâ'ya İmkânın Tarihi, İstanbul: Klasik, 2011.

Mâtürîdî, Ebû Mansûr Muhammed. Kitâbü't-Tevhîd. nşr. Fethullah Huleyf; İskenderiye: y.y. ts.

Mâtürîdî, Ebû Mansûr Muhammed. Te'vîlâtü Ehli's-sünne. nşr. Fatıma Yusuf el-Hıyamî, Beyrut: Müessesetü'r-Risâle, 2004.

Nesefi, Ebü'l-Muîn. Tebsıratu'l-edille fî usûli'd-dîn. nşr. Claude Salâme. Dımaşk: 1993.

Pezdevî, Ebü'I-Yüsr Muhammed. nşr. H.P. Lins. Usûlü'd-dîn. Kâhire: Dâru İhyâi'I-Kütübi'lArabiyye, 1963.

Râzî, Fahreddîn. Mefâtihu'l-gayb. 3. Baskı. Beyrut: Dârü Ihyâi't-Türâsi'l-Arabiyye, 1981.

Râzî, Fahreddîn. el-Metâlibü'l-âliye mine'l-ilmi'l-ilâhî. nşr. Ahmed Hicâzî es-Sakâ. Beyrut: Dârü'l-Kitâbi'l-Arabî, 1987.

Şehristânî, Abdülkerîm. Nihâyetü'l-ikdâm, nşr. Alfred Guilaume, Kâhire: Mektebetü'sSekâfeti'd-Dîniyye, 2009.

Şehristânî, Abdülkerîm. Mes'ele fî isbâti'l-cevheri'l-ferd. nşr. A. Guilaume, (Nihâyetü'likdâm'ın sonunda). Kâhire: Mektebetü's-Sekâfeti'd-Dîniyye, 2009.

Teftazânî, Sa'deddîn Mes'ud b. Ömer. Şerhu'I-Akâid. Dersaâdet: Şirket-i Sahâfî-i Osmâniyye Matbaası, 1326.

Teftazânî, Sa'deddîn Mes'ud b. Ömer. Şerhu'I-Makâsıd. nşr. Abdurrahman U'meyrâ. Beyrut: Âlemü'l-Kütüb, 1989.

Tehânevî, Muhammed Ali b. Ali. "Heyûlâ". Keşşâfü ıstılahâti'l-fünûn. Beyrut: Mektebetü Lübnân, ts.

Ülken, H. Ziya. Eski Yunan'dan Çağdaş Düşünceye Doğru İslam Felsefesi. İstanbul: Ülken Yayınları, 1993.

Yavuz, Y. Şevki. “Adem”. Türkiye Diyanet Vakfı İslâm Ansiklopedisi. 1: 357. İstanbul: 1988.

Zemahşerî, Keşşâf. nşr. Âdil A. Abdulmevcûd-Ali M. Muavvız. Riyad: Mektebetü'lUbeyd,1998. 